\title{
Pleistocene loess deposits and mollusc assemblages in the Eastern Pre-Alps
}

\author{
Christa Frank, Birgit Terhorst, Bodo Damm, Christine Thiel, Manfred Frechen, Robert Peticzka
}

\begin{abstract}
:
In comparison to other areas in low mountain regions, the widespread occurrence and thickness of loess is impressive in the northern Vienna Forest. Due to differences in grain size, it is obvious that the loess deposits of the Hagenbach Valley deviate from those of other locations. In comparison to the results of Krems and Stillfried, the loess of the Hagenbach Valley has a pronounced maximum in the sand fraction reflecting an essential influence of the Flysch sandstone and a proximity to the source sarea. The loess of the Hagenbach Valley is specified as sediment with significant local impact due to a remarkable influence of short distance transport. Partly, the loess is of alluvial origin as it contains small pebbles and therefore it reflects cool and wet paleoenvironmental conditions. The malacological evidences coincide with the geomorphodynamic conditions. Redeposition processes cause a generally high degree of fragmentation. The malacological analyses proved 28 species of terrestrial gastropoda, with a total number of 3,283 specimens. The results indicate very humid and cool climate and a weakly expressed, slightly more favorable period is visible in one of the horizons.
\end{abstract}

[Pleistozäne Lösssedimente und Molluskengesellschaften in der östlichen Voralpenzone]

Kurzfassung:

Die Lössablagerungen im nördlichen Wienerwald sind im Vergleich mit anderen Mittelgebirgsregionen aufgrund ihrer Mächtigkeit sehr eindrucksvoll. Charakterista in der Korngrößenverteilung zeigen deutlich, dass die Lösse im Hagenbachtal sich von denen anderer Lösssgebiete unterscheiden. Ein Vergleich mit Lössprofilen in Krems und Stillfried hat ergeben, dass der Löss im Hagenbachtal einen erhöhten Sandanteil aufweist und damit den Einfluss der Flysch-Sandsteine widerspiegelt. Das spricht für einen lokalen Sedimenteintrag und kurze äolische Transportstrecken. Zudem wurde der Löss unter kühl-humiden Paläoklimabedingungen zum Teil als Schwemmlöss abgelagert. Die malakologischen Ergebnisse stimmen mit den geomorphodynamischen Bedingungen überein. Die Umlagerungsprozesse haben zu einer intensiven Fragmentierung der Schalenreste geführt. Die malakologischen Untersuchungen belegen insgesamt 28 unterschiedliche Arten von terrestrischen Gastropoden mit 3283 Individuen. Die paläoökologische Auswertung spricht für sehr humide, kühle Klimabedingungen mit einer schwach ausgeprägten, klimatisch etwas günstigeren Phase.

Keywords: $\quad$ Molluscs, dating, loess, low mountain area, Vienna Forest, Upper Pleistocene

Addresses of authors: C. Frank, University of Vienna, Department of Anthropology, Althanstr. 14, A-1090 Vienna/Austria; B. Terhorst, University of Würzburg, Institute of Geography and Geology, Am Hubland, D-97074 Würzburg/Germany. E-Mail: birgit. terhorst@uni-wuerzburg.de; B. Damm, University of Vechta, ISPA, Universitätsstr. 5, D-49377 Vechta/Germany. E-Mail: bdamm@ispa.uni-vechta.de; C. Thiel and M. Frechen, Leibniz Institute for Applied Geophysics, S3: Geochronology and Isotope Hydrology, Stilleweg 2, D-30655 Hannover/Germany. E-Mail: Christine.thiel@liag-hannover.de; Manfred.frechen@ liag-hannover.de.; R. Peticzka, University of Vienna, Institute of Geography and Regional Research, Althanstr. 14, A-1090 Vienna/Austria.

\section{Introduction}

In Lower Austria, eolian sediments are widespread (Fig. 1) and form thick and well developed loess sequences. These deposits of Lower Austria have been studied for several decades. Detailed descriptions and sedimentological data exist for many loess/paleosol sequences situated in the basins of Vienna and the Alpine foreland (FINK 1976; KoHL 1976; Haesaerts et al. 1996, Terhorst 2007, Peticzka et al. 2010). Geochronological framework for these deposits are most commonly based on radiocarbon (e.g. HAESEARTS et al. 1996) and luminescence dating (WALLNER et al. 1990; Noll et al. 1994, Zöller et al. 1994; ThIEL et al. 2011a, $2011 b, c)$. Both dating methods are suitable, at least for the time range of up to $40 \mathrm{ka}$ for radiocarbon (HAJDAs 2008) and to $300 \mathrm{ka}$ for luminescence (THIEL et al. 2011a), for the sediments under question and have been proven to be reliable approaches.

While detailed descriptions, sedimentological and chronological data exist for many loess/paleosol sequences in the
Vienna basin and the Alpine foreland (e.g. FINK 1956, 1976, 1978; KuKLA 1975, DöPPES \& RABEDER 1997, Terhorst 2007), loess sediments in the low mountain areas have not been studied up to present. The map of loess distribution for Lower Austria clearly shows that loess covers the northern margins of the Vienna Forest (Fig.1). There, loess deposits are frequent and occur in altitudes above $300 \mathrm{~m}$ a.s.l. and reach remarkable thicknesses of $4 \mathrm{~m}$ in steep slope positions (DAmm \& Terhorst 2010). Inside the Hagenbach Valley, loess sequences are exposed by landslide processes.

Conforming to several studies, the Vienna Forest offers excellent and suitable conditions for the development of rich malacocoenoses (KLEMM 1974; REISCHÜTZ 1986, 1988; FrANK 1988/89, 1992; TröstL, 1996, 1997a, b, 1998a, b, 1999, 2000). The variable landscape and favorable climate, the diversity of plant assemblages and the Pleistocene periglacial paleoenvironment offer multifarious possibilities for molluscan life in different ecological niches (mixed deciduous woods, underwood, herbaceous vegetation, mild humus, litter and dead wood, rocky ground). 


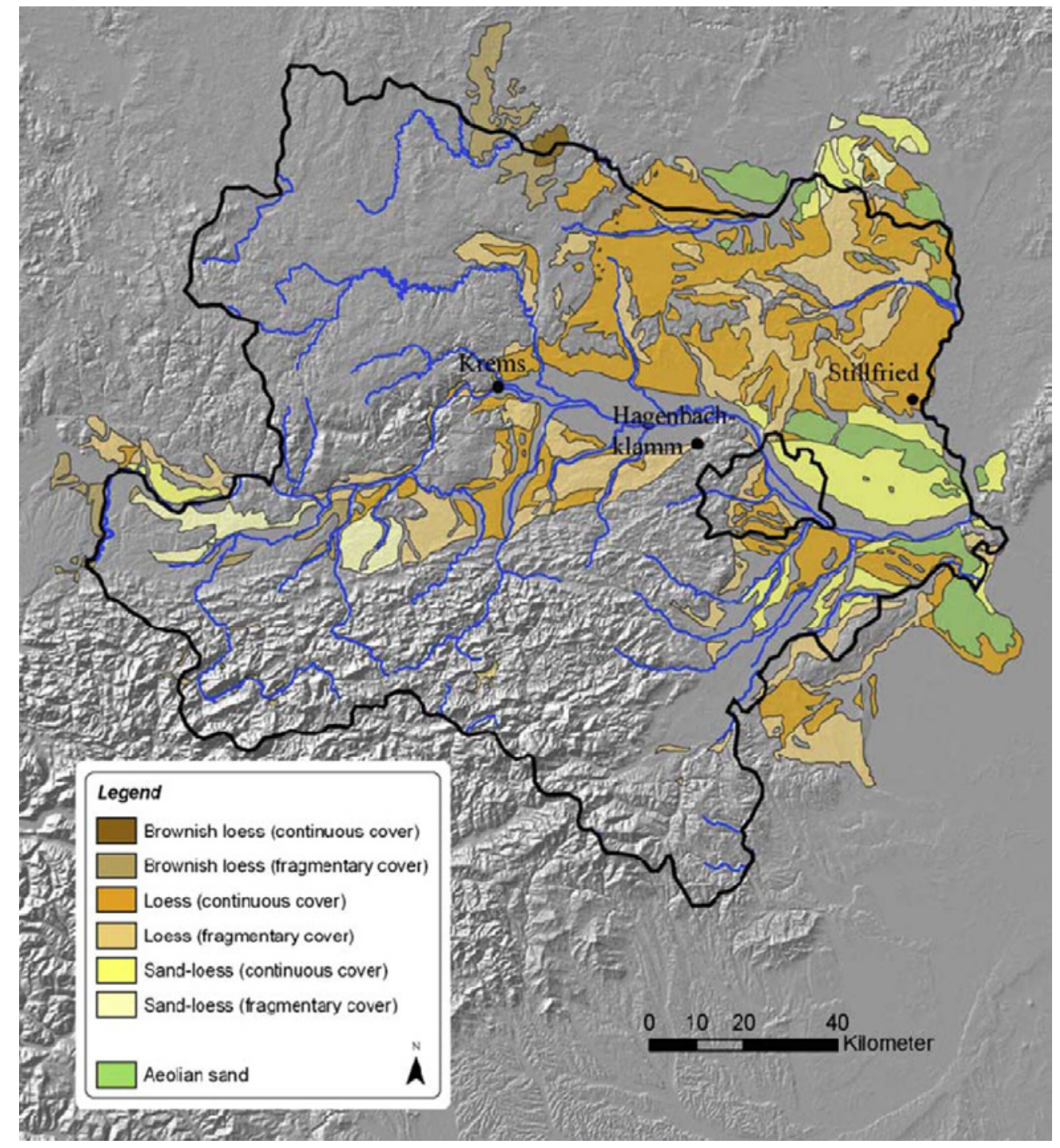

Fig. 1. Loess distribution map of Lower Austria with study sites (black points) (TERHORST et al. 2009).

Abb. 1. Lössverbreitungskarte von Niederösterreich mit Untersuchungsgebieten (TERHORST et al. 2009).

In general, the malacological analyses of a complete pedosedimentary sequence of the Hagenbach Valley are promising for insights into the faunal and paleoenvironmental development during the last Middle to Late Glacial period.

Two characteristic sequences and first dating results combining both radiocarbon and luminescence dating are presented with a focus on mollusc analyses in this study. The results are compared to characteristic loess sequences of Lower Austria.

\section{Study area}

The Hagenbach Valley (Hagenbachklamm) is situated approximately $16 \mathrm{~km}$ to the NW of the city of Vienna (Fig. 2). Climate data for the period between 1971 and 2000 show mean annual temperature of $9.2^{\circ} \mathrm{C}$ and mean annual precipitation of $741.5 \mathrm{~mm}$ (ZAMG 2002). The valley is part of the northern margin of the Vienna Forest that represents a rolling landscape of the Central European low mountain regions. The flat-topped mountains of the Vienna Forest with altitudes between 300 and $500 \mathrm{~m}$ a.s.l. are deeply incised by valleys.

The study area belongs to the Rhenodanubian Flysch Zone, which is W-E oriented and consists of various layers of (calcareous) sandstones, marly shales, calcareous marls and clay schists. The formations inside the Hagenbach Valley belong to the Altlengbach and the Greifenstein beds. They are dominated by calcareous quartzitic sandstones, which are subdivided by stratified marls and clays (Wessely 2006).

The slopes of the Hagenbach Valley are characterized by various types of Quaternary sediments. The bedrock is covered by loess and Pleistocene periglacial cover beds.

First results concerning Quaternary slope deposits have been published by DAMm $\mho$ Terhorst (2010) and Terhorst et al. (2009). However, the chronology of loess deposits and periglacial layers is not known up to present in the Vienna Forest.

\section{Methods}

\section{Field survey and sedimentological analyses}

The description and determination of soil horizons were conducted according to the German Field Book for Soil Survey (AD-HOC-ArBeITSGruppe BodEN 2005). The field description was adapted to the World Reference Base for soil resources (IUSS Working Group WRB, 2006). During the field survey information on texture, bedding, content of carbonate, and colour of soils and sediments was gathered. The differentiation of periglacial cover beds was based on 


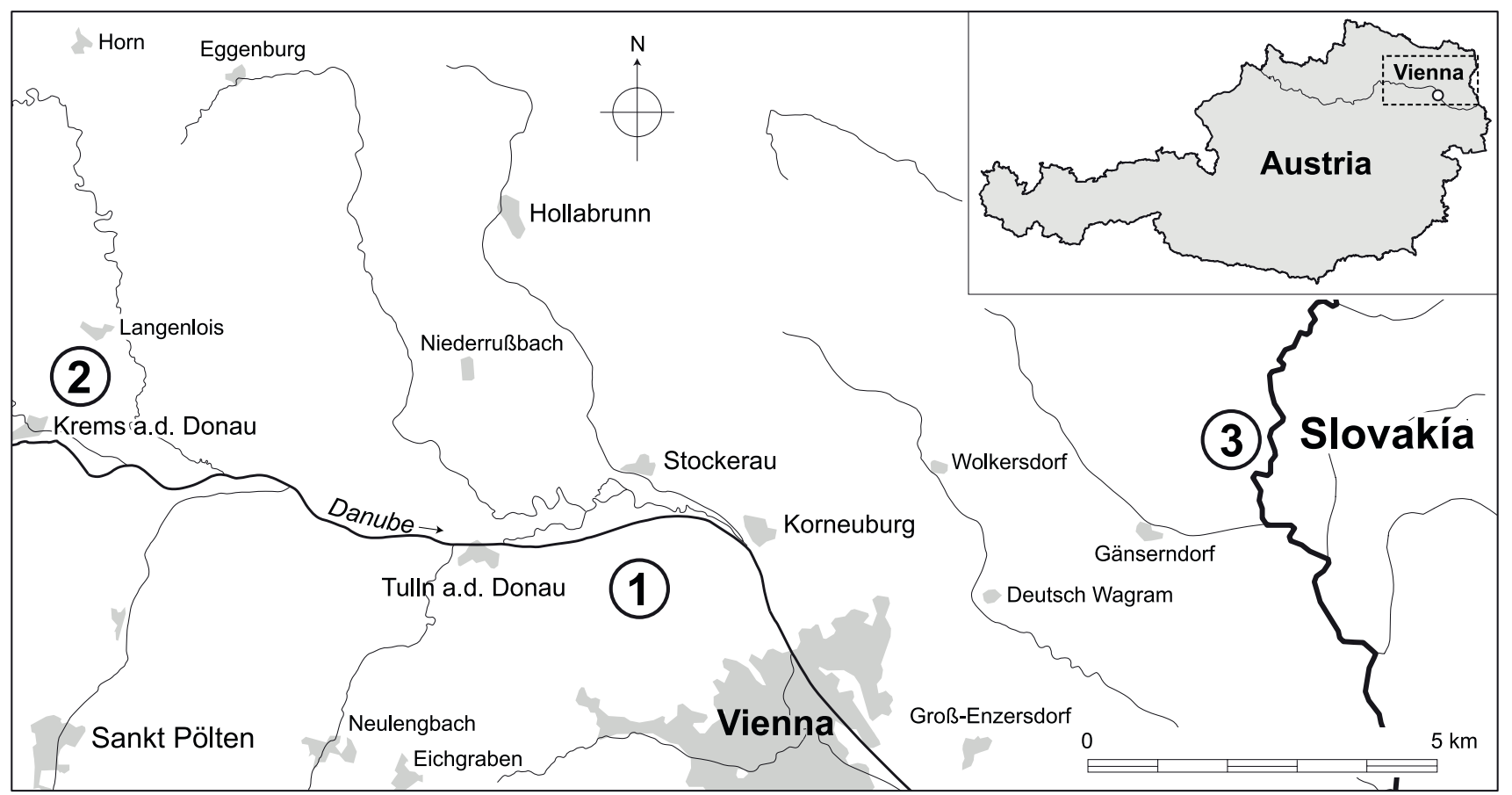

Fig. 2. Study areas in the Vienna Forest and in the loess regions of Lower Austria. $1=$ Hagenbach Valley, $2=$ Krems, $3=$ Stillfried .

Abb. 2. Untersuchungsgebiete im Wienerwald und in den Lössregionen Nierderösterreichs. $1=$ Hagenbachklamm, $2=$ Krems, $3=$ Stillfried .

the German Field Book for Soil Survey (AD-HOC-ARBEITsGRUPPE BODEN 2005). The main criteria were given by sedimentological features such as the occurrence of specific silt contents and rock fragments, which are essential indicators for the differentiation of periglacial cover beds (SEMMEL \& Terhorst 2010). Samples were taken by horizons. Two sequences (A and B) are presented in detail (Fig. 3).

Laboratory analyses included grain size determination according to the combined sieve- and pipette-analysis according to Köhn (Schlichting et al. 1995). The calcium carbonate contents $\left(\mathrm{CaCO}_{3}\right)$ were measured gasvolumetrically with the Scheibler instrument.

\section{Radiocarbon and luminescence dating}

For age determination both radiocarbon and luminescence dating have been applied. Whereas radiocarbon dating estimates the time elapsed since the death of an organism (e.g. HAJDAS 2008), luminescence dating techniques determine the time passed since the last exposure of mineral grains to sunlight, and thus enable to constrain the time of deposition (AITKEN 1998).

The radiocarbon age (Hv25871) was obtained from charcoal using gas proportional counters. The sample was taken in Sequence B at a depth of $3.9 \mathrm{~m}$ in loessic sediments. The calculation of the radiocarbon age is based on the radioactive half-life after Libby, i.e. 5568 years. The age was fitted to the international radiocarbon timescale by NBS oxalic acid standard; the data is $\delta^{13} \mathrm{C}$ corrected. All uncertainties of the chemical and technical treatment of the sample are included in the expressed age error (2-sigma standard deviation).

Two luminescence samples were taken in the loess of Sequence A (Fig. 3) by hammering metal tubes into the freshly cleaned profile; sample 1217 was taken at a depth of $2.4 \mathrm{~m}$ and sample 1218 at $3.1 \mathrm{~m}$, respectively. Luminescence measurements were made with an automated Risø TL/OSL read- ers (DA-15; BøTTER-JENSEN et al. 2003) equipped with a calibrated ${ }^{90} \mathrm{Sr} /{ }^{90} \mathrm{Y}$ beta source. The feldspar signal of the polymineral samples was stimulated with infra-red (IR) light diodes emitting at $870 \mathrm{~nm}$, and the luminescence was detected in the blue-violet region through a Schott BG39/Corning 7-59 filter combination.

For equivalent dose $\left(D_{\mathrm{e}}\right)$ determination, a single-aliquot regenerative (SAR; MURRAY \& WINTLE 2000) protocol with a preheat of $250^{\circ} \mathrm{C}(60 \mathrm{~s})$ and IR stimulation at $50^{\circ} \mathrm{C}$ for $100 \mathrm{~s}$ was applied. An IR illumination at $280^{\circ} \mathrm{C}(100 \mathrm{~s})$ was inserted at the end of each SAR cycle (Murray \& WintLe 2003). The laboratory fading rate was measured as the IRSL signal decrease over time using artificially irradiated ali-quots (LAмотнE et al. 2003); this is expressed in terms of the percentage decrease of signal intensity per decade (the $g$-value; Aitken 1985, Appendix F).

Material for dosimetry measurements (as part of the luminescence dating) were taken from immediately around the luminescence samples. After drying and homogenizing, $50 \mathrm{~g}$ of each sample were packed in N-type beakers, which were stored at least for one month to ensure equilibrium between radon and its daughter nuclides. The concentrations of $\mathrm{U}$, Th and $\mathrm{K}$ were determined by high-resolution gamma-ray spectrometry. The dose rates were derived using the conversion factors of ADAMIEC \& AitKen (1998). Calculation of the cosmic dose rate is based on Prescott \& Hutton (1994). A water content of $20 \pm 5 \%$ was estimated, allowing for changes in water content throughout time, and a mean a-value of $0.08 \pm 0.01$ was used.

\section{Mollusc analyses}

Soaked samples $(1000 \mathrm{~g})$ were treated by wet sieving to $2 \mathrm{~mm}-$ $630 \mu \mathrm{m}$ and $200 \mu \mathrm{m}$ mesh, dried and selected. The $200 \mu \mathrm{m}$ fraction contained thousands of minute fragments, so only the significant ones (apices, apertures) were picked out for calculating the individual numbers (as proposed by LožEK 1964). 
Tab. 1: Grain size and calcium carbonate content of sequences A and B, modified after TERHORST et al. (2009).

Tab. 1: Ergebnisse der Korngrößen- und Kalziumkarbonatanalysen der Profile A und B, geändert nach TERHORST et al. (2009).

\begin{tabular}{|c|c|c|c|c|c|c|c|c|c|c|c|}
\hline \multirow[t]{3}{*}{ Sample } & \multirow{3}{*}{$\begin{array}{c}\text { Horizon/layer } \\
\mu \mathrm{m} \\
\end{array}$} & \multirow{3}{*}{\begin{tabular}{c|} 
Clay \% \\
$<2$ \\
\end{tabular}} & \multicolumn{4}{|c|}{ Silt \% } & \multicolumn{4}{|c|}{ Sand \% } & \multirow{3}{*}{$\begin{array}{c}\mathrm{CaCO}_{3} \\
\% \\
\%\end{array}$} \\
\hline & & & fine & middle & coarse & total & fine & middle & coarse & total & \\
\hline & & & $2-6$ & $6-20$ & $20-63$ & & $63-200$ & $200-630$ & $630-2000$ & & \\
\hline \multicolumn{12}{|c|}{ Sequence A } \\
\hline $6-1$ & Luvisol, E horizon & 19.0 & 6.3 & 15.6 & 40.4 & 62.3 & 16.9 & 1.5 & 0.3 & 18.7 & 0 \\
\hline $6-2$ & Luvisol, EBt horizon & 25.4 & 5.4 & 12.5 & 38.6 & 56.5 & 16.6 & 1.3 & 0.2 & 18.1 & 0 \\
\hline $6-3$ & Luvisol, Bt horizon & 29.5 & 4.1 & 10.6 & 35.1 & 49.7 & 19.1 & 1.4 & 0.3 & 20.8 & 0 \\
\hline $6-4$ & C1, loess, upper part & 6.8 & 3.4 & 9.0 & 43.1 & 55.5 & 33.8 & 3.2 & 0.7 & 37.7 & 34.9 \\
\hline $6-5$ & C1, loess, lower part & 7.8 & 3.4 & 10.6 & 48.0 & 62.0 & 22.4 & 3.6 & 4.2 & 30.2 & 36.2 \\
\hline $6-6$ & C2, loess & 7.4 & 4.0 & 10.0 & 45.5 & 59.5 & 30.0 & 2.2 & 0.9 & 33.1 & 36.2 \\
\hline $6-7$ & $\begin{array}{l}\text { C3, basal periglacial } \\
\text { cover bed }\end{array}$ & 31.8 & 19.7 & 20.8 & 13.3 & 53.8 & 4.8 & 4.1 & 5.5 & 14.4 & 31.9 \\
\hline 7 & Flysch marls & 23.3 & 6.4 & 16.1 & 35.6 & 58.1 & 16.1 & 2.3 & 0.2 & 18.6 & $\begin{array}{c}\text { not } \\
\text { measured }\end{array}$ \\
\hline 8 & $\begin{array}{l}\text { Decomposed Flysch } \\
\text { sandstone }\end{array}$ & 7.1 & 4.7 & 9.4 & 17.6 & 31.7 & 35.0 & 20.6 & 5.6 & 61.2 & 6.0 \\
\hline 10 & $\begin{array}{l}\text { Decomposed Flysch } \\
\text { sandstone }\end{array}$ & 3.0 & 1.8 & 5.3 & 10.3 & 17.4 & 36.0 & 42.3 & 1.4 & 79.7 & 2.8 \\
\hline 11 & $\begin{array}{l}\text { Decomposed Flysch } \\
\text { sandstone }\end{array}$ & 4.0 & 2.6 & 6.3 & 11.1 & 19.9 & 31.6 & 39.9 & 4.6 & 76.1 & 41.7 \\
\hline \multicolumn{12}{|c|}{ Sequence B } \\
\hline $17-1$ & Luvisol, Bt horizon & 33.8 & 5.9 & 12.8 & 33.9 & 52.5 & 11.8 & 1.6 & 0.3 & 13.7 & 3.7 \\
\hline $17-3$ & $\mathrm{C} 1,1.5 \mathrm{~m}$, loess & 6.7 & 3.4 & 15.1 & 50.7 & 69.2 & 19.3 & 2.4 & 2.4 & 24.1 & 33.9 \\
\hline $17-4$ & $\mathrm{C} 1,2.0 \mathrm{~m}$, loess & 9.6 & 4.3 & 8.2 & 55.4 & 67.9 & २०.२ & 1.1 & 1.1 & 22.5 & 23.0 \\
\hline $17-5$ & C1, 2.3m, loess & 11.3 & 5.0 & 14.4 & 54.2 & 73.5 & 13.0 & 1.2 & 1.0 & 15.2 & २२.3 \\
\hline $17-6$ & C1 $2.5 \mathrm{~m}$, loess & 10.2 & 4.7 & 13.7 & 56.6 & 75.0 & 12.3 & 1.3 & 1.1 & 14.8 & 23.2 \\
\hline $17-7$ & C2, 2.0m, loess & 13.2 & 5.2 & 15.0 & 55.2 & 75.4 & 9.4 & 1.1 & 0.8 & 11.3 & 23.4 \\
\hline $17-8$ & C2, 2.8m, loess & 14.8 & 4.8 & 15.7 & 49.7 & 70.2 & 12.4 & 1.6 & 1.0 & 14.9 & 23.4 \\
\hline $17-9$ & c2, 3.0m, loess & 13.9 & 5.2 & 15.8 & 52.7 & 73.7 & 10.4 & 1.4 & 0.5 & 12.3 & 21.8 \\
\hline $17-10$ & C2, $3.7 \mathrm{~m}$, loess & 18.1 & 5.7 & 16.7 & 47.3 & 69.7 & 8.6 & 2.3 & 1.2 & 12.2 & 20.7 \\
\hline $17-11$ & C2, 4.0m, loess & 15.6 & 5.5 & 15.4 & 49.5 & 70.5 & 11.5 & 1.7 & 0.7 & 13.9 & 21.4 \\
\hline 17-12 & $\begin{array}{l}\text { C3, basal periglacial } \\
\text { cover bed }\end{array}$ & 9.0 & 2.6 & 5.1 & 10.6 & 18.4 & 25.6 & 32.6 & 14.1 & 72.6 & 9.7 \\
\hline
\end{tabular}

\section{Results}

\section{Field survey and sedimentological analyses}

Two sequences at a distance of $300 \mathrm{~m}$ were studied. The altitude of both profiles ranges between $260 \mathrm{~m}$ and $310 \mathrm{~m}$ a.s.l.. Sequence $\mathrm{A}$ is situated on the western slope of the Hagenbach Valley, sequence B on the eastern slope. Both loess deposits are situated on top of basal periglacial cover bed (Flysch debris) superimposed on Flysch. In general, a Luvisol is developed on top of the loess.

\section{Sequence A}

The sequence starts with a Luvisol consisting of a thin A horizon, an E horizon, partly followed by a transitional EBt horizon, Bt horizon and, as parent material, loess that forms the $\mathrm{C}$ horizon (Fig. 3). Soil horizons are free of calcium carbonate and show a loose structure interspersed with pores of different sizes.

Below the $1 \mathrm{~m}$ thick Luvisol, a loess deposit with a thick- ness of $1.4 \mathrm{~m}$ is recorded (Fig. 4). The loess shows a pale yellow colour, involves partly small rounded sandstone fragments as well as secondary carbonates. On average, the silt content in the loess deposits is higher than in related soil horizons. Inside the silt fraction, coarse silt constitutes with values from $43.1 \%$ to $48.0 \%$ makes up the most important fraction (Table 1: 6-4 to 6-6), whereas the fine and middle silt contents are comparatively small. The loess has low clay contents with a maximum value of $7.8 \%$. The carbonate content of the unweathered loess deposits ranges from $34.9 \%$ to $36.2 \%$ (Table 1). The basal part of the loess (Fig. 3) is characterized by the occurrence of hydromorphic features such as thin brownish and grayish Fe-bands.

Below the eolian deposits, a periglacial cover bed is present, which consists of clays, marls, and debris (Fig. 3). The clay content amounts to $31.8 \%$, the silt content to $53.8 \%$ and the sand fraction is lower than in the previously described layers. The carbonate content is $31.9 \%$. The consistence and distribution inside the silt classes deviates from those of the loess. In 


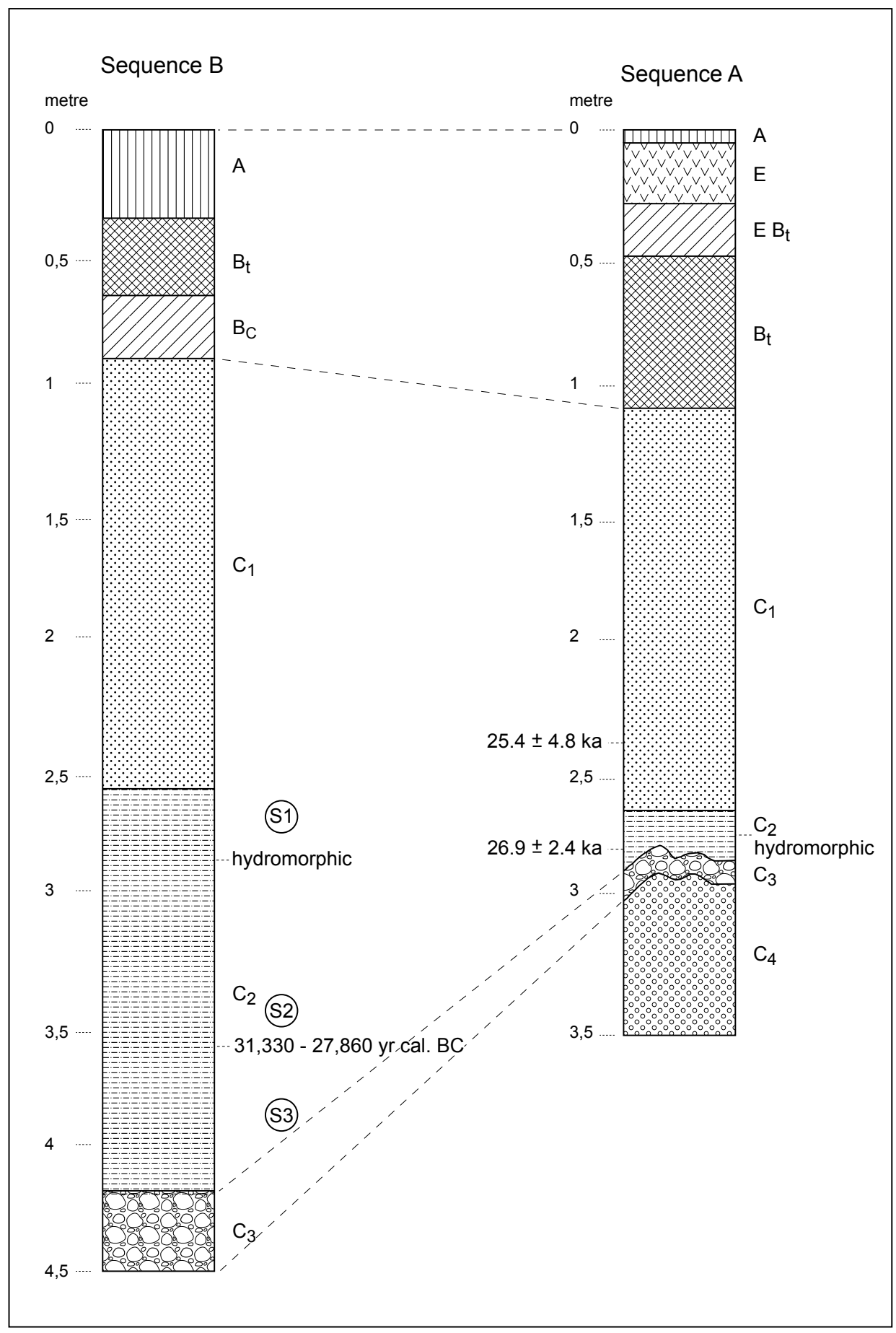

Fig. 3. Loess sequences $A$ and $B$ in the Hagenbach Valley. The profile illustrates the Flysch basement (C4), the basal periglacial cover beds with marls, and sandstone debris (C3), the loess deposits (C1, C2), the Bt horizons of the Luvisos $(A / B)$ as well as the E/EBt horizon (A). The recent soil in sequence $B$ corresponds to an eroded Luvisol.

Abb. 3. Lössprofil A und B in der Hagenbachklamm. Das Profil zeigt den basalen Flysch (C4), die Basislage mit Mergeln und Sandsteinschutt (C3), Lösssedimente (C1, C2), den Bt-Horizont der Parabraunerde $(A / B)$ sowie den $E /$ EBt-Horizont (A). Der rezente Boden in Profil B stellt eine erodierte Parabraunerde dar.

the case of the periglacial cover bed the contents of fine, middle, and coarse silt are more or less homogeneously distributed. The stratum is densely bedded, has an intensively undulated boundary and the debris is composed of Flysch bedrock. The latter meets the diagnostic pre-requisites for the classification as a Pleistocene basal periglacial cover bed.

Samples were taken in the surface formations of the Flysch sandstones to compare loess deposits with the local bedrock (Table 1: 8, 10, 11). Weathered bedrock varies in carbonate content between $2.8 \%$ and $6.0 \%$, whereas the carbonate content of less weathered Flysch bedrock can reach values up to $41.7 \%$ and reflects the potential carbonate level of the bedrock (Table 1: 11).

Samples that originate from decomposed sandstone are certainly dominated by the sand fraction, which varies be- tween $61.2 \%$ and $79.7 \%$ (Table $1: 8,10,11$ ). It is two to three times higher than in the loess and marls. The maximum contents are in the middle and fine sand fraction, whereas the coarse fraction is of minor importance. Silt contents range between $17.4 \%$ and $31.7 \%$ with maxima in coarse silt.

\section{Sequence B}

The second example of a characteristic pedosedimentary sequence (Fig. 3, B) is situated on the E slope of the Hagenbach Valley, in about $300 \mathrm{~m}$ linear distance from sequence A. The upper part of the sequence is formed by a Bt horizon of an eroded Luvisol, disturbed by anthropogenic impact and redeposition of colluvial material. The eroded Luvisol has formed in loess, which has a remarkable thickness of $3.5 \mathrm{~m}$. The upper part of the pale yellow loess shows low clay con- 


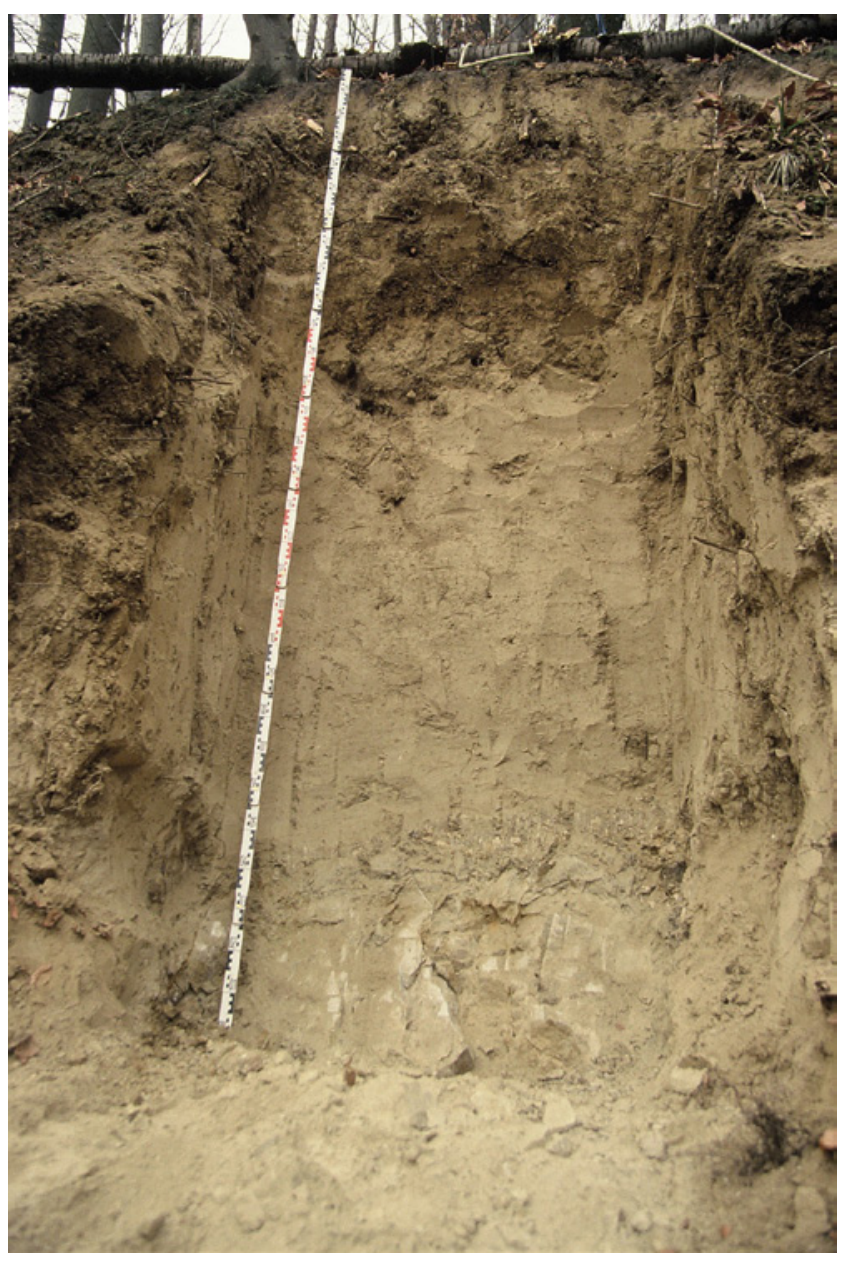

Fig. 4. Loess sequence A in the Hagenbach Valley. Loess deposit on top of Flysch sediments. The uppermost part corresponds to a Haplic Luvisol (see Fig. 3). Abb. 4. Lössprofil A in der Hagenbachklamm. Lösssedimente auf Flyschgesteinen. Der oberste Profilabschnitt zeigt eine Parabraunerde (vgl. Abb. 3).

tents between $6.7 \%$ and $10.2 \%$ (Table $1: 17-3$ to $17-6$ ). The silt content dominates the grain size distribution and reaches values up to $75.0 \%$. The sand content ranges from $14.8 \%$ to $24.1 \%$. The $\mathrm{CaCO}_{3}$ contents are on average about $23 \%$, and only the parts of the sequence, which have secondary carbonates, contain more $\mathrm{CaCO}_{3}(33.9 \%$, Table 1: 17-3). In the basal parts of the loess hydromorphic features are present (Fig. 3). The horizon C2 is interspersed with small mottles and bands of rusty iron alternating with grayish mottles of reduced iron. The lowermost horizon, C3 (17-12) consists of sandstone debris and sand, which is exclusively made of Flysch sediments. This debris layer corresponds to the Pleistocene basal periglacial cover bed of sequence A. It consists of local bedrock fragments with stone fragments orientated related to the slope inclination.

\section{Comparison of loess sites in Lower Austria}

The characteristics of the loess deposits of the Hagenbach Valley differ significantly from other loess deposits in Lower Austria (Table 2). The loess sediments of the Vienna Forest show a higher percentage in the sand fraction and lower clay content. However, the silt fraction is comparable with those of the loess sequence in Stillfried (Table 2: 20-1 and $20-2)$. There is a significant analogy in the coarse silt fraction for all study sites. On the contrary, the loess of Krems contains, with values up to $83.5 \%$, significantly more silt in total as well as in the coarse silt fraction (Table 2: $59.1 \%$ to $62.3 \%$ ). In general, the portion of middle silt is higher in the loess regions and reduced in the Vienna Forest study sites.

\section{Dating}

The charcoal sampled in Sequence B was dated to 31,330-27,860 years cal. BC (Table 3; calibration after REIMER et al. 2009).

For the luminescence samples the dose recovery tests for all aliquots were within $10 \%$ of unity, showing the applicability of the protocol to our samples. Recycling ratios, which show the ability of a measurement protocol to reproducibly measure the response to a laboratory dose given after repeated heating of the sample, are close to unity $(1.01 \pm 0.01 ; n=30)$, and are hence very satisfactory. Furthermore, recuperation for all aliquots was measured to be $<5 \%$. The dose rates of 2.4 $\pm 0.2 \mathrm{~Gy} / \mathrm{ka}$ and $2.7 \pm 0.2 \mathrm{~Gy} / \mathrm{ka}$, respectively, are in the range known from Lower Austrian loess deposits (e.g. THIEL et al. 2011a, b, c; ZöLLER et al. 1994) (Table 3).

The fading uncorrected age for sample 1217 is $20.7 \pm 3.7$ $\mathrm{ka}$, and sample 1218 was dated to $22.2 \pm 1.2 \mathrm{ka}$. However, for both samples a fading rate of $>2 \% /$ decade was measured, implying that these uncorrected ages are underestimating the depositional age. Fading correction had to be applied; this is based on Equation 4 of HuntLey \& LAmothe (2001). The fading corrected ages of $25.4 \pm 4.8 \mathrm{ka}$ (sample 1217) and $26.9 \pm 2.4 \mathrm{ka}$ (sample 1218) are considered more reliable.

\section{Mollusc analyses / Coenological analysis}

Mollusc samples (Table 4 and Table 5) originate from the lower part of the loess sequence B (Fig. 3). They have been taken in a vertical order from the sample position S1 (top) to S3 (base). In sample S2 there is a remarkable decrease in total number of individuals (S1: 1344, S2: 843). However, in sample $\mathrm{S} 3$ the number of species is declining (S2: 25, S3: 21), whereas the number of individuals increases noticeably (1106) (Fig. 5 and Fig. 6).

Singular shell fragments of highly demanding woodland species appear only in S1 and S2: Ena montana and Ruthenica filograna in both of them, cf. Cochlodina laminata only in S1, Aegopinella cf. nitens only in S2. Semilimax kotulae has been found all over the profile. This species occurs also in thanatocoenoses (=mollusc assemblages) pointing to moderate or cold climate. The first-mentioned species are allochthoneous in samples S1 and S2.

There is a range of features common to all three thanatocoenoses (from S1 to S3):

- Petrophile character due to the clausiliid species Neostyriaca corynodes austroloessica (rates: S1: 5.7\%, S2: 9.8\%, S3: 7.4\%) and Clausilia dubia (S1: 2.4\%, S2: 4.6\%, S3: 4.3\%).

- The presence of Orcula dolium.

- The percentage rates of all three species are 9.0\% (S1), $15.4 \%$ (S2) and $13.1 \%$ (S3).

- The indication of humidity due to the predominance of Trochulus hispidus and Trochulus suberectus (together: S1: 61.7\%, S2: 47.9\%, S3: 55.0\%).

- Elements inhabiting areas of medium humidity, with herbaceous vegetation, hedges or clumps of trees are more distinctly represented in S2 (12\%) and S3 (12.2\%) than in S1 $(3.9 \%)$.

- The percentage rates of Pupilla species (mostly: sterrii, fur- 
thermore triplicata and bigranata) are very low; $\mathrm{S} 1:<0.9 \%$, S2: $3.6 \%$ and S3: $<2.8 \%$.

- Loess elements occur only scarcely with the highest percentages in samples S1 (9.4\%). The percentages of S2 and S3 are lower (5.5\% and 6.7\%, respectively).

- Cold-resistant species Vertigo modesta arctica (WALlENBERG 1858) and Vertigo parcedentata (BRAUN 1847) occur nowhere in the profile.
- Cochlicopa lubrica and Euconulus praticola, which are species indicating humid to damp microhabitats appear only in negligible percentages (S1: $0.7 \%$, S2: 0.5\%, S3: $0.8 \%$ ).

- The percentages of Succinella oblonga, a species frequently associated with Trochulus hispidus, in the Upper Pleistocene layers are rather insignificant (S1: $2.1 \%, \mathrm{~S} 2: 3.9 \%, \mathrm{~S} 3$ : $3.1 \%$; in S1: single specimens of $f$. elongata).

- Orcula dolium infima (ZimmERMANn 1932), a subspecies

Tab. 2: Grain size and calcium carbonate content of sequences A and B in comparison to analyses of loess profiles of Krems and Stillfried in Lower Austria (TERHORST et al. 2009).

Tab. 2: Ergebnisse der Korngrößen- und Kalziumkarbonatanalysen der Profile A und B, im Vergleich mit den Analysen der Lössprofile in Krems und Stillfried in Niederösterreich (TERHORST et al. 2009).

\begin{tabular}{|c|c|c|c|c|c|c|c|c|c|c|}
\hline \multirow[t]{3}{*}{ Sample } & \multirow[t]{3}{*}{ Profile } & \multirow[t]{2}{*}{ Clay } & \multicolumn{4}{|c|}{ Silt } & \multicolumn{4}{|c|}{ Sand } \\
\hline & & & fine & middle & coarse & total & fine & middle & coarse & total \\
\hline & & $<2$ & $2-6$ & $6-20$ & $20-63$ & & $63-200$ & $200-630$ & $630-2000$ & \\
\hline $6-4$ & $\begin{array}{l}\text { Vienna Forest, Hagenbach, } \\
\text { loess [E slope] }\end{array}$ & 6.8 & 3.4 & 9.0 & 4,1 & 55.5 & 33.8 & 3.2 & 0.8 & 37.7 \\
\hline $6-5$ & $\begin{array}{l}\text { Vienna Forest, Hagenbach, } \\
\text { loess [E slope] }\end{array}$ & 7.8 & 3.4 & 10.6 & 48.0 & 62.0 & 22.4 & 3.6 & 4.2 & 30.2 \\
\hline $6-6$ & $\begin{array}{l}\text { Vienna Forest, Hagenbach, } \\
\text { loess [E slope] }\end{array}$ & 7.4 & 4.0 & 10.0 & 45.5 & 59.5 & 30.0 & 2.2 & 0.9 & 33.1 \\
\hline $17-3$ & $\begin{array}{l}\text { Vienna Forest, Hagenbach, } \\
\text { Loess [W slope] }\end{array}$ & 6.7 & 3.4 & 15.1 & 50.7 & 68.2 & 19.3 & 2.4 & 2.4 & 24.1 \\
\hline $17-4$ & $\begin{array}{l}\text { Vienna Forest, Hagenbach, } \\
\text { loess [W slope] }\end{array}$ & 9.6 & 4.3 & 8.2 & 55.4 & 67.9 & 20.2 & 1.1 & 1.1 & 22.5 \\
\hline $17-5$ & $\begin{array}{l}\text { Vienna Forest, Hagenbach, } \\
\text { Loess [W slope] }\end{array}$ & 11.3 & 5.0 & 14.4 & 54.2 & 73.5 & 13.0 & 1.2 & 1.0 & 15.2 \\
\hline $\begin{array}{l}18-1 \\
{[\mathrm{~B} 16 / 9]}\end{array}$ & $\begin{array}{l}\text { Loess region, Krems- } \\
\text { Wachtberg }\end{array}$ & 14.0 & 4.3 & 15.0 & 61.9 & 81.2 & 6.7 & 0.6 & 0.1 & 7.4 \\
\hline $\begin{array}{l}18-2 \\
{[B 16 / 10]}\end{array}$ & $\begin{array}{l}\text { Loess region, Krems- } \\
\text { Wachtberg }\end{array}$ & 13.5 & 3.4 & 17.3 & 59.1 & 79.8 & 6.9 & 0.4 & 0.1 & 7.4 \\
\hline $\begin{array}{l}19-1 \\
{[S W 1]} \\
\end{array}$ & $\begin{array}{l}\text { Loess region, Krems- } \\
\text { Hundsteig }\end{array}$ & 15.3 & 4.4 & 14.8 & 59.8 & 79.0 & 8.2 & 1.1 & 0.3 & 9.6 \\
\hline $\begin{array}{l}19-2 \\
{[S W 7]}\end{array}$ & $\begin{array}{l}\text { Loess region, Krems- } \\
\text { Hundsteig }\end{array}$ & 12.4 & 3.6 & 17.6 & 62.3 & 83.5 & 7.4 & 0.6 & 0.1 & 8.1 \\
\hline $\begin{array}{l}20-1 \\
\text { [StillB10] }\end{array}$ & Loess region, Stillfried & 17.7 & 5.0 & 12.8 & 47.9 & 65.7 & 10.5 & 2.5 & 0.1 & 13.1 \\
\hline $\begin{array}{l}20-2 \\
\text { [StillB14] }\end{array}$ & Loess region, Stillfried & 18.6 & 5.9 & 15.8 & 40.8 & 62.5 & 10.6 & 2.1 & 0.1 & 12.8 \\
\hline
\end{tabular}

Tab. 3: Radiocarbon age and IRSL ages (fading uncorrected and fading corrected) and its corresponding information (dose rates, equivalent doses, fading rates). Tab. 3: Radiokarbon- und IRSL-Alter (nicht korrigiert und korrigiert für anomales Ausheilen und korrigiert) und die dazugehörigen Informationen (Dosisleistung, Äquivalenzdosis und Fadingrate).

\begin{tabular}{|l|l|l|l|}
\hline Lab ID & Hv25871 & LUM 1217 & LUM 1218 \\
\hline Sequence & B & A & A \\
\hline Depth [m] & 3.6 & 2.35 & 2.90 \\
\hline Material & charcoal & sediment & sediment \\
\hline Dating Method & 14 C & IRSL & IRSL \\
\hline$\delta^{13}$ C [\%o] & $-24,3$ & - & - \\
\hline Conventional age [a BP] & $26,950 \pm 1,665$ & - & - \\
\hline Calibrated age [a cal. BC] & $31,330-27,860$ & - & - \\
\hline Dose rate [Gy/ka] & - & $2.7 \pm 0.2$ & $2.4 \pm 0.2$ \\
\hline De $[$ Gy] & - & $56.3 \pm 3.6$ & $54.1 \pm 1.1$ \\
\hline g-value [\%/decade] & - & $2.6 \pm 0.3$ & $2.4 \pm 0.3$ \\
\hline uncorrected age [ka] & - & $20.7 \pm 3.7$ & $22.2 \pm 1.2$ \\
\hline corrected age [ka] & - & $25.4 \pm 4.8$ & $26.9 \pm 2.4$ \\
\hline
\end{tabular}




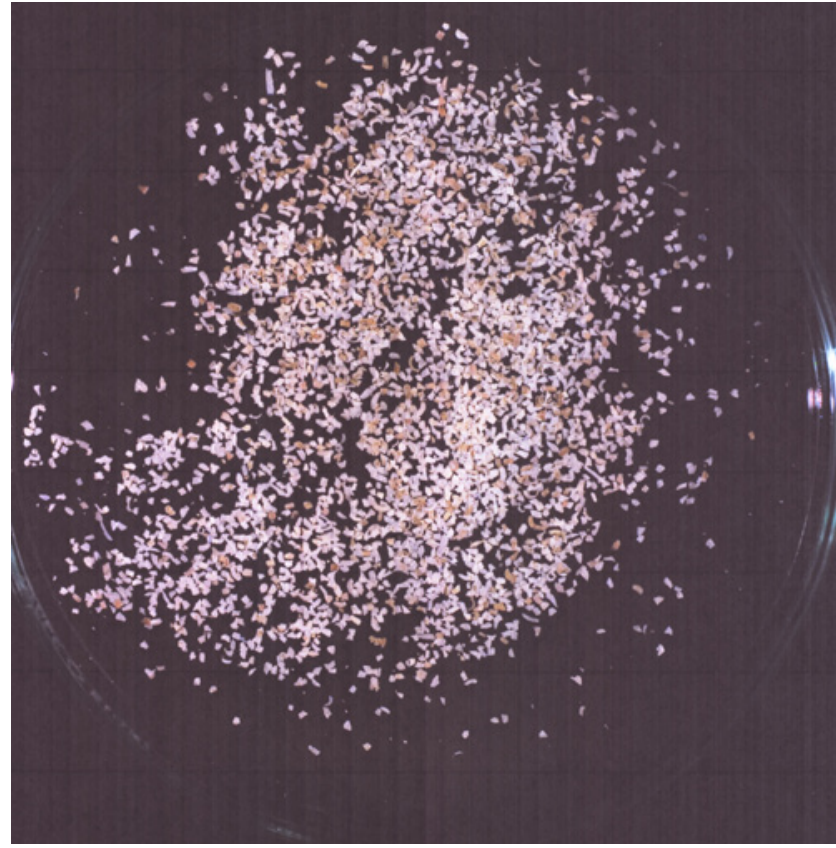

Fig. 5. Mollusc assemblage of sample S1 (see Table 4 and 5).

Abb. 5. Molluskengesellschaft in der Probe S1 (vgl. Tab. 4 und 5).

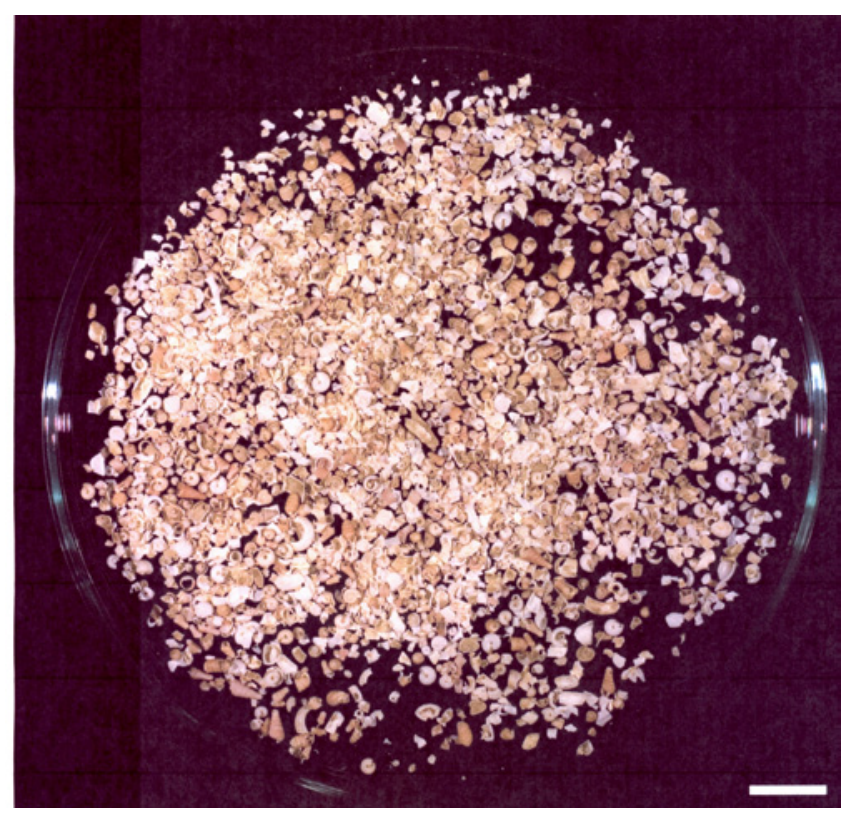

Fig. 6. Mollusc assemblage of sample S3 (see Table 4 and 5).

Abb. 6. Molluskengesellschaft in der Probe S3 (vgl. Tab. 4 und 5).

living in present day malacocoenoses in the neighbourhood of the excavation area, does not occur in the studied samples. This large form seems to be restricted to some regions of the Vienna Forest, at colline to low-mountain altitudes with favourable climate.

- Contaminations and redeposition of material is expressed in the thanatocoenoses of horizons S1 and S2, at a depth of 2.8-3.7m, where single minute, corroded shell fragments of highly demanding woodland species (Ena montana, Cochlodina laminata, Ruthenica filograna, Aegopinella nitens) appear. These species certainly occurred in the study area during the middle Holocene climatic optimum but also live there today.

\section{Discussion}

In comparison to central European low mountain regions, the widespread occurrence and thickness of loess is impressive in the northern Vienna Forest. It is clearly distinguishable from other sediments such as periglacial cover beds and decomposed Flysch bedrock. Furthermore, loess deposits of the characteristic loess regions of Lower Austria can be clearly distinguished. Due to differences in grain size, it is obvious that the loess deposit of the Hagenbach Valley deviates from those of the other locations. The loess profiles of Krems and Stillfried show the characteristic grain size distribution of periglacial eolian sediments with an enhanced input of grains originating from a far distance transport (PÉcsI \& RICHTER 1996). In comparison to the results of Krems and Stillfried, the loess of the Hagenbach Valley has a pronounced maximum in the sand fraction, thus reflecting an essential influence of the Flysch sandstone. However, short distance eolian transport is significantly higher in the area under study than in the main loess regions of Lower Austria. Therefore, the loess of the Hagenbach Valley might be specified as sediment with a considerable local impact. Partly, the loess has been redeposited as it contains small pebbles and therefore it reflects cool and wet paleoenvironmental conditions. The results of the datings might be interpreted in this way as well.

The malacological evidences coincide with geomorphodynamic processes like erosion and sedimentation as assumed by DAmm \& Terhorst (2007, 2010), DAmm et al. (2008), and TERHORST et al. (2009). Furthermore, redeposition of loess is suggested by the generally high degree of fragmentation of molluscs shells, especially in sample S1. The periglacial origin of the sediments is reflected by the structure of the thanatocoenoses, which is distinctly contradictory to the rich and varied molluscan assemblage of today.

Malacological evidence points to comparatively least favorable paleoenvironmental factors during the deposition of the uppermost part of the basal loess (Fig. 3, S1). The conditions reflected in the lowermost sample S3 are equally infavorable, but of mitigated character, whereas the sedimentation period of S2 appears slightly moderated.

Following this, the sedimentation period is marked by very humid and cool climate, which does not coincide with the occurrence of very manifold vegetation:

- mainly open to semi-open, probably tundra-like areas

- predominantly herbaceous vegetation and undemanding trees or brushwood

- not very extensive damp habitats

- rocks overgrown with mosses and lichens, shady or exposed

Although the three thanatocoenoses reflect rather cold climate, extreme conditions are nowhere recognizable, indicated by the low percentage rates of the typical loess species Pupilla, Vallonia tenuilabris and Columella columella, the absence of cold-tolerant Vertigo's, the obviously not very differentiated structure of the thanatocoenoses, the mass development of the Trochulus species, and the presence of the Neostyriaca corynodes subspecies austroloessica. According to KLEMM (1969), the latter is associated with environmental conditions similar to those in the Eastern Alps from about 
Tab. 4: Species list with absolute numbers.

Tab. 4: Liste der Spezies mit absoluten Zahlen.

\begin{tabular}{|c|c|c|c|c|c|c|}
\hline Family & Genus & Species & s1 & s2 & S3 & Total \\
\hline Succineidae & Succinella J.MABiLle 1871 & S. oblonga [Draparnaud 1801] & $28^{1}$ & 33 & 34 & 95 \\
\hline Cochlicopidae & Cochlicopa A.FérussaC 1821 & C. lubrica [O.F.MüLleR 1774] & 4 & 3 & 3 & 10 \\
\hline Orculidae & Orcula HeLd 1838 & O. dolium [Draparnaud 1801] & 12 & 8 & 15 & 35 \\
\hline \multirow[t]{2}{*}{ Valloniidae } & Vallonia Rısso 1826 & V. costata [O.F.MüLLeR 1774] & 7 & 4 & 12 & 23 \\
\hline & & V. tenuilabris [A.Braun 1843] & 1 & 3 & 3 & 7 \\
\hline \multirow[t]{7}{*}{ Pupillidae } & Pupilla Fleming 1828 & P. alpicola densegyrata LožEK 1954] & 21 & 8 & 17 & 46 \\
\hline & & P. muscorum [Linnaeus 1758] & 15 & 7 & 8 & 30 \\
\hline & & P. bigranata [RossmaessLer 1839] & 1 & - & 3 & 4 \\
\hline & & P. triplicata [S. Studer 1820] & 3 & 3 & 5 & 11 \\
\hline & & P. sterrii [Vолтн 1840] & 8 & 27 & 23 & 58 \\
\hline & & P. loessica [Lozek 1954] & 6 & 2 & 1 & 9 \\
\hline & & Apices & $81^{2}$ & $26^{3}$ & $45^{4}$ & 152 \\
\hline \multirow[t]{2}{*}{ Vertiginidae } & Columella Westerlund 1878 & C. columella [G.v.MARTENS 1830] & 3 & 1 & - & 4 \\
\hline & Vertigo O.F. MüLleR 1773 & V. substriata [JEFFREYs 1833] & 1 & - & - & 1 \\
\hline Enidae & Ena TuRTon 1831 & E. montana [DRAPARnaud 1801] & $2^{5}$ & $1^{6}$ & - & 3 \\
\hline \multirow[t]{5}{*}{ Clausiliidae } & Cochlodina A. Férussac 1821 & C. laminata [MontAGu 1803] & $1^{7}$ & - & - & 1 \\
\hline & Ruthenica LINDHOLM 1924 & R. filograna [RosSMAESSLER 1836] & $1^{8}$ & $1^{9}$ & - & 2 \\
\hline & Clausilia Draparnaud 1805 & & & & & \\
\hline & Clausilia [Andraea] L. PfFIFFER 1848 & C. [A.] dubia [Draparnaud 1805] & 32 & 39 & 48 & 119 \\
\hline & Neostyriaca A.J.WAGNER 1920 & $\begin{array}{l}\text { N. corynodes [HELD 1836]: austroloessica } \\
\text { [KLEMM 1969] }\end{array}$ & 77 & 83 & 82 & 242 \\
\hline Punctidae & Punctum Morse 1864 & P. pygmaeum [Draparnaud 1801] & 39 & 34 & 19 & 92 \\
\hline Pristilomatidae & Vitrea FITZINGER 1833 & V. crystallina [O.F.MüLLER 1774] & 32 & 86 & 111 & 229 \\
\hline \multirow[t]{2}{*}{ Euconulidae } & Euconulus ReINHARDt 1883 & E. fulvus [0.F.MüLleR 1774] & 5 & 3 & 1 & 9 \\
\hline & & E. praticola [REINHARDT 1883] & 5 & 1 & 6 & 12 \\
\hline Oxychilidae & Aegopinella LINDHoLm 1927 & A. nitens [Mıсначd 1831] & - & $3^{10}$ & - & 3 \\
\hline \multirow[t]{2}{*}{ Vitrinidae } & Semilimax Agassiz 1845 & & & & & \\
\hline & Semilimax [Hessemilimax] Schıцеүко 1986 & S. [H.] kotulae [WESTERLund 1883] & 1 & 1 & 4 & 6 \\
\hline \multirow[t]{4}{*}{ Hygromiidae } & Euomphalia WesterLund 1889 & E. strigella [Draparnaud 1801] & 1 & - & - & 1 \\
\hline & Trochulus CHeMnitz 1786 & T. hispidus [ LINNAEus 1758] & 452 & 204 & 294 & 950 \\
\hline & & T. suberectus [CLESSIN 1878] & 377 & 200 & 314 & 891 \\
\hline & & T. sp.: Embryonic whorls & $112^{11}$ & $50^{12}$ & $48^{13}$ & 210 \\
\hline \multirow[t]{2}{*}{ Helicidae } & Arianta TuRTON 1831 & A. arbustorum [LinNaEus 1758] & 16 & 12 & 10 & 38 \\
\hline & & Total number & 1,344 & 843 & 1,106 & 3,293 \\
\hline
\end{tabular}

1 single specimens: +/- var. elongata (Sandberger 1875), 2 most of them: muscorum, alpicola densegyrata, 3 most of them: alpicola densegyrata, loessica 4 muscorum, alpicola densegyrata, loessica, 5 fragments of body whorl, 6 atypical fragment, $7 \mathrm{cf}$. fragment of aperture, $8 \mathrm{cf}$. fragment of body whorl, 9 atypical fragment, $10 \mathrm{cf}$. two of them: fragments of body whorl, 11 hispidus + suberectus, 12 like in S1, 13 like in S1 and S2

Tab. 5: Minute, atypical fragments, estimated number (S3: ca. 3,700 fragments, S1: ca. 5,700 fragments).

Tab. 5: Winzige, unspezifische Windungsfragmente, geschätzte Anzahl (S3: ca. 3.700 Fragmente, S1: ca. 5.700 Fragmente).

\begin{tabular}{|c|c|c|c|c|}
\hline & s1 & s2 & s3 & Total \\
\hline Number & $\sim 5.750$ & 2.150 & 3.700 & 11.600 \\
\hline Contents & $\begin{array}{l}\text { Mostly Trochulus hispidus, } \\
\text { Trochulus suberectus, Orcula } \\
\text { dolium, Clausilia dubia, } \\
\text { Neostyriaca corynodes. }\end{array}$ & $\begin{array}{l}\text { Mostly both Trochulus sp., } \\
\text { Neostyriaca corynodes, } \\
\text { Clausilia dubia. }\end{array}$ & $\begin{array}{l}\text { Mostly both Trochulus sp., } \\
\text { Clausilia dubia, Neostyriaca } \\
\text { corynodes, Pupilla sp., Vitrea } \\
\text { crystallina, also Arianta } \\
\text { arbustorum, Euconulus } \\
\text { sp., Cochlicopa lubrica, } \\
\text { Succinella oblonga. }\end{array}$ & \\
\hline
\end{tabular}


1,400 m upwards to about 2,300 m asl. KLEMm (1969) has listed the occurrence in different loess deposits in the Danube Valley of Upper and Lower Austria (c.f. Frank 2006).

Furthermore, the absence of large Orcula dolium specimens is worth mentioning in this context, since the study area is situated within the "infima zone" sensu ZimMERmanN (1932) and Klemm (1974). Local populations of such "fattened" forms would rather point to optimum living conditions. Therefore, one may conclude that this large subspecies that occur nowadays in the southern and eastern Vienna Forest have developed subsequently during the Postglacial warming.

In general, there is good agreement between malacological results and the obtained dating results. The slightly older age estimate for the charcoal compared to the luminescence age could be either due to problems in fading correction as observed by others (e.g. WALLINGA et al. 2007), i.e. even after fading correction the luminescence ages are underestimates, or due to reworking and correspondingly later incorporation of the charcoal into the hydromorphic unit C2. However, within two standard deviations, there is good agreement of the obtained ages.

Both, ${ }^{14} \mathrm{C}$ - and IRSL-dating indicate deposition of loess and loess-like sediments prior to the Last Glacial Maximum. This is consistent with formerly presented luminescence ages of $\sim 25-30$ ka (THIEL et al., 2011a, b, c) for loess deposits in the Kremser Feld. From these studies it seems evident that the phase of loess deposition during the Last Glacial Maximum is not well documented in Lower Austria, whereas the period between $\sim 25-30$ ka can be found in several outcrops, for instance in Stillfried (cf. FrANK 1997), in the archaeological sites Willendorf (HAEsAERTs et al. 1996), and KremsWachtberg (Neugebauer-MAResch 2008). Hence, the observations made for the Hagenbach Valley fit to results obtained from other loess sequences of Lower Austria. However, there is still a lack of high resolution dating in relevant profiles, also for the Hagenbach Valley. Moreover, investigations have focussed on the relevant archaeological horizons of a sequence (HAEsAERTs et al. 1996), and younger loess might not have been observed due to sampling and dating strategies. It is evident that loess/paleosol sequences of the LGM are ubiquitous in Upper Austria (Terhorst et al. 2002; STARNBERGER et al. 2009).

\section{Acknowledgements}

We would like to thank C. Hermann (University of Vienna, Institute of Geography and Regional Research) for laboratory assistance, G. Hillebrand (Zoological Garden of Vienna / Schönbrunn) for picking the numerous shell fragments and S. Pohl (University of Vienna, Facility for Cell Imaging and Ultrastructure Research) for taking the photographs. We are grateful to S. Riemenschneider (Leibniz Institute for Applied Geophysics) for preparation of the luminescence samples. Furthermore, we thank Gudrun Drewes and Petra Posimowski for preparation and measurement of the radiocarbon sample.

\section{References}

Adamiec, G. \& Aitken, M. J. (1998): Dose-rate conversion factors: update. - Ancient TL, 16: 37-50.

AD-HOC-Arbeitsgruppe Boden (2005): Bodenkundliche Kartieranleitung. - 438 pp., 5th ed., Hannover.

Aitken, M. J. (1985): Thermoluminescence Dating. - 359 pp., Academic Press, London.

Aitken, M. J. (1998): An introduction to optical dating - The Dating of Quaternary Sediments by the Use of Photon-Stimulated Luminescence. - 267 p., Oxford University Press, Oxford.

Bøtter-Jensen, L., Andersen, C. E., Duller, G. A. T. \& Murray, A. S. (2003): Developments in radiation, stimulation and observation facilities in luminescence measurements. - Radiation Measurements, 37: 535-541.

DAmm, B. \& Terhorst, B. (2007): Quaternary slope formation and landslide susceptibility in the Flysch Zone of the Vienna Forest (Austria). - Geomorphology for the Future, Innsbruck University Press, Innsbruck (Austria), pp. 89-96.

DAmm, B. \& Terhorst, B. (2010): A model of slope formation related to landslide activity in the Eastern Prealps, Austria. Geomorphology, 122/3-4: 338-350.

Damm, B., Terhorst, B., Köttritsch, E., Ottner, F. \& Mayrhofer, M. (2008): Zum Einfluss bodenphysikalischer und bodenmechanischer Parameter in quartären Deckschichten auf Massenbewegungen im Wienerwald. - Abhandlungen der Geologischen Bundesanstalt, 62: 33-37.

Döppes, D. ひ RABEDER, G. (Eds.) (1997): Pliozäne und pleistozäne Faunen Österreichs. - pp. 123-130, Verlag der Österreichischen Akademie der Wissenschaften, Wien.

Fink, J. (1956): Zur Korrelation der Terrassen und Lösse in Österreich. Eiszeitalter und Gegenwart, 7: 49-77.

Fink, J. (1976): Exkursion durch den österreichischen Teil des nördlichen Alpenvorlandes und den Donauraum zwischen Krems und Wiener Pforte. - Erweiterter Führer zur Exkursion aus Anlass der 2. Tagung der IGCP-Projektgruppe, Quaternary Glaciations in the Northern Hemisphere'. Mitteilungen der Kommission für Quartärforschung der Osterreichischen Akademie der Wissenschaften, 1: 113 p.

FinK, J. (1978): Exkursion durch den österreichischen Teil des nördlichen Alpenvorlandes und den Donauraum zwischen Krems und Wiener Pforte. - Ergänzung zu Band 1. Mitteilungen der Kommission für Quartärforschung der Österreichischen Akademie der Wissenschaften, 2: $31 \mathrm{p}$.

FrANK, C. (1988/89): Ein Beitrag zur Kenntnis der Molluskenfaunen Österreichs. Zusammenfassung der Sammeldaten aus Salzburg, Oberösterreich, Niederösterreich, Steiermark, Burgenland und Kärnten (1965-1987). - Jahrbuch für Landeskunde Niederösterreichs, pp. $85-144$

FrANK, C. (1992): Malakologisches aus dem Ostalpenraum. - Linzer Biologische Beiträge, 24/2: 383-662.

Frank, C. (1997): Stillfried-Typusprofile. In: Döppes, D. \& RABEder, G. (Eds.): Pliozäne und pleistozäne Faunen Österreichs. - pp. 123-130, Verlag der Österreichischen Akademie der Wissenschaften, Wien.

FrANK, C. (2006): Plio-pleistozäne und holozäne Mollusken Österreichs. Teil 1 und 2. - Mitteilungen der Prähistorischen Kommission der Österreichischen Akademie der Wissenschaften 62: 1-395; 397-860.

Haesaerts, P., Damblon, F., Bachner, M. \& Trnka, G. (1996): Revised stratigraphy and chronology of the Willendorf II sequence, Lower Austria. - Archaeologia Austriaca, 80: 25-42.

HajDAs, I. (2008): Radiocarbon dating and its application in Quaternary studies. - Eiszeitalter und Gegenwart, 57: 2-24.

HuntLEY, D. J. \& LAMOTHE, M. (2001): Ubiquity of anomalous fading in Kfeldspars and the measurement and correction for it in optical dating. - Canadian Journal of Earth Science, 38: 1093-1106.

IUSS Working Group WRB, 2006. World Reference Base for Soil Resources. - World Soil Resources Reports 103, FAO, Rome.

KLemm, W. (1969): Das Subgenus Neostyriaca A.J. WAGNER 1920, besonders der Rassenkreis Clausilia (Neostyriaca) corynodes HELD 1836. Archiv für Molluskenkunde, 99(5/6): 285-311, Frankfurt/Main.

Klemm, W. (1974): Die Verbreitung der rezenten Land-Gehäuse-Schnecken in Österreich. - Denkschrift Österreichische Akademie der Wissenschaften, 117: 503pp., Springer Verlag, Wien/New York. 
KoHL, H. (1976): Lehmgrube der Ziegelei Würzburger in Aschet bei Wels. - Mitteilungen der Kommission für Quartärforschung der Österreichischen Akademie der Wissenschaften, 1: 37-41.

KuKLA, G.J. (1975): Loess stratigraphy of central Europe. In: K.W. Butzer and L.I. Isaac, Editors, After Australopithecenes, Mouton Publishers, The Hague, pp. 99-187.

lamothe, M., Auclair, M., Hamzaoui, C. \& Huot, S. (2003): Towards a prediction of long-term anomalous fading of feldspar IRSL. - Radiation Measurements, 37: 493-498.

LožEK, V. (1964): Quartärmollusken der Tschechoslowakei. - Rozpravy ústrědního ústavu geoglogichékho, 31: 374 p., Prag.

MurRaY, A. S. \& WintLe, A. G. (2000): Luminescence dating of quartz using an improved single-aliquot regenerative-dose protocol. - Radiation Measurements, 32: 57-73.

Murray, A. S. \& Wintle, A. G. (2003): The single aliquot regenerative dose protocol: potential for improvements in reliability. - Radiation Measurements, 37: 377-381.

Neugebauer-Maresch, C. (2008): Krems-Hundssteig - Mammutjägerlager der Eiszeit. - 347 p., Verlag der Österreichischen Akademie der Wissenschaften, Wien.

Noll, M., Leitner-Wild, E., Hille, P. (1994): Thermoluminescence dating of loess deposits at Paudorf, Austria. Quaternary Geochronology (Quaternary Science Reviews), 13: 473-476.

PÉCSI, M. ひ RICHTER, G. (1996): Löss Herkunft - Gliederung - Landschaften. - Zeitschrift für Geomorphologie, N. F. Suppl., $98: 391$ p.

Peticzka, R., Holawe, F., Riegler, D. (2010): Structural analyses on the modified paleosol-sequence of "Stillfried B" with high resolution measurements of selected laboratory parameters. - Quaternary International, 222: 168-177.

Prescott, J. R. \& Hutton, J. T. (1994): Cosmic ray contributions to dose rates for luminescence and ESR dating: large depths and long-term variations. - Radiation Measurements, 23: 497-500.

Reimer, P.J., Baillie, M.G.L., Bard, E., Bayliss, A., Beck, J.W., Bertrand, C.J.H., Blackwell, P.G., Buck, C.E., Burr, G.S., Cutler, K.B., Damon, P.E., Edwards, R.L.,Fairbanks, R.G., Friedrich, M., Guilderson, T.P., Hogg, A.G., Hughen, K.A., Kromer, B., McCormac, F.G., Manning, S., Bronk Ramsey, C., Reimer, R.W., Remmele, S., Southon, J.R., Stuiver, M., Talamo, S., Taylor, F.W., van der Plicht, J. \& WeyhenmeYER, C.E. (2004): IntCal04 terrestrial radiocarbon age calibration, 0-26 cal kyr BP. - Radiocarbon, 51: 1111-1150.

ReIschütz, P. L. (1986): Die Verbreitung der Nacktschnecken Österreichs (Arionidae, Milacidae, Limacidae, Agriolimacidae, Boettgerillidae). Sitzungsberichte der Österreichischen Akademie der Wissenschaften, Mathemathisch-naturwissenschaftliche Klasse, Abt. I, 195(1-5): 67-190, Springer Verlag, Wien/New York.

REISCHÜTZ, P. L. (1988): Contributions to the mollusc fauna of Lower Austria, VII. The distribution of the Hydrobioidae of Lower Austria, Vienna and Burgenland. - De Kreukel, 1963: 67-87.

Schlichting, E., Blume, H.-P. ¿STAhr, K. (1995): Bodenkundliches Praktikum. - 295 pp., Blackwell, Wien.

Semmel, A. \& Terhorst, B. (2010): The concept of the Pleistocene periglacial cover beds in Central Europe - A review. Quaternary International 222/1-2: 120-128.

Starnberger, R., Terhorst, B., Rähle, W., Peticzka, R. \& HaAs, J.N. (2009): Paleoecology of periglacial environments during OIS-2 in the forefields of the Salzach Glacier (Upper Austria). - Quaternary International, 198: 51-61.

Terhorst, B., Frechen, M. \& Reitner, J. (2002): Chronostratigraphische Ergebnisse aus Lößprofilen der Inn- und Traun-Hochterrassen in Oberösterreich. - Zeitschrift für Geomorphologie N.F., 127: 213-232.

Terhorst, B. (2007): Korrelation von mittelpleistozänen Löß-/Paläobodensequenzen in Oberösterreich mit einer marinen Sauerstoffisotopenkurve. E \& G Quaternary Science Journal, 56/3: 172-185.

Terhorst, B. Damm, B., Peticzka, R. \& Köttritsch, E. (2009): Reconstruction of Quaternary landscape formation as a tool to understand present geomorphological processes in the Eastern Prealps (Austria). - In: Costantini, E., Makeev, A. \& SAuer, D. (eds.): Recent Developments and New Frontiers in Paleopedology. Quaternary International, 209: 66-78.
Terhorst, B., Frechen, M. \& Reitner, J. (2002): Chronostratigraphische Ergebnisse aus Lößprofilen der Inn- und Traun-Hochterrassen in Oberösterreich. - Zeitschrift für Geomorphologie, N. F. Suppl., 127: 213-232.

Thiel, C., Buylaert, J.-P., Murray, A. S., Terhorst, B., Hofer, I., TsukaMOTO, S. \& FRECHEN, M. (2011a): Luminescence dating of the Stratzing loess profile (Austria) - Testing the potential of an elevated temperature post-IR IRSL protocol. - Quaternary International. 234/1-2: 23-31.

Thiel, C., Buylaert, J.-P., Murray, A. S., Terhorst, B., Tsukamoto, S. FRECHEN, M. (2011b): Investigating the chronostratigraphy of prominent palaeosols in Lower Austria using post-IR IRSL dating. - E\&G Quaternary Science Journal.

Thiel, C., Terhorst, B., Jaburová, I., Buylaert, J.-P., Murray, A. S. Fladerer, F. A., DAmm, B., Frechen, M. \& OtTner, F., (2011C): Quaternary landscape evolution in Lower Austria revealed in the brickyard of Langenlois. Geomorphology. doi:10.1016/j.geomorph.2011.02.011.

TRÖSTL, R. A. (1996): Faunistisch-ökologische Untersuchungen der Molluskenfauna verschiedener Mischwaldtypen des Wienerwaldes (OstÖsterreich). - 226 p., phD thesis University of Vienna.

TRöstL, R. A. (1997a): Faunistisch-ökologische Betrachtungen der Schneckengemeinschaften des Wienerwaldes. 1. Gipfel-Eschenwald (Aceri-Carpinetum subass. aegopodietosum KLIKA $1941 \mathrm{em}$. HUSOVÁ 1982) des Hermannskogels und Linden-Kalkschutthalden-Wald (Aceri carpinetum KLIKA 1941 s.l.) des Leopoldsberges. - Verhandlungen der Zoologisch-Botanischen Gesellschaft Österreich, 134: 7-91, Wien.

TRöstL, R. A. (1997b): Faunistisch-ökologische Betrachtungen der Schneckengemeinschaften des Wienerwaldes. 2. Eichen-Hainbuchenwälder (Verband Carpinion betuli ISSLER 1931) des Leopolds-, Latisund Gränberges; 3. Wärmeliebende Eichenmischwälder (Ordnung Quercetalia pubescentis KLIKA 1933) des Leopoldsberges. - Verhandlungen der Zoologisch-Botanischen Gesellschaft Österreich, 134: 93-117, Wien.

TRöstL, R. A. (1998a): Faunistisch-ökologische Betrachtungen der Schneckengemeinschaften des Wienerwaldes. 4. Waldmeister-Buchenwald (Asperulo odoratae-Fagetum SOUGNEZ \& THILL 1959) des Kahlenberges, Hinterhainbachs (Umgebung), des Hermannskogels und Gränberges; 5. Wimperseggen-Buchenwald (Carici pilosae-Fagetum OBERDORFER 1957) des Sauberges. - Verhandlungen der Zoologisch-Botanischen Gesellschaft Österreich, 135: 231-258.

TröstL, R. A. (1998b): Faunistisch-ökologische Betrachtungen der Schnecken-gemeinschaften des Wienerwaldes. 6. Grenzwaldkomplex des Kalenderberges (Mödlinger Klause). - Verhandlungen der Zoologisch-Botanischen Gesellschaft Österreich, 135: 259-270.

TRÖsTL, R. A. (1999): Faunistisch-ökologische Betrachtungen der Schneckengemeinschaften des Wienerwaldes. 7. Synoptische Schlußbetrachtung. - Verhandlungen der Zoologisch-Botanischen Gesellschaft Österreich, 136: 127-147.

TRÖSTL, R. A. (2000): Über das Vorkommen von Orcula dolium (DRAPARNAUD, 1801) im nordöstlichsten Teil des Flysch-Wienerwaldes. Verhandlungen der Zoologisch-Botanischen Gesellschaft Österreich, 137: $147-152$.

Wallinga, J., Bos, A. J. J., Dorenbos, P., Murray, A. S. \& Schokker, J. (2007): A test case for anomalous fading correction in IRSL. Quaternary Geochronology, 2: 216-221.

Wallner, G., Wild, E., Aref-Azar, H., Hille, P. \& Schmidt, W.F.O. (1990): Dating of Austrian loess deposits. Radiation Protection Dosimetry, 34: 69-72.

Wessely, G. (2006): Geologie der Österreichischen Bundesländer - Niederösterreich. - Geologische Bundesanstalt Wien, pp. 416.

ZAMG (2002): Klimadaten von Österreich 1971-2000. Klimadaten von über 200 Stationen in ganz Österreich. - Daten-CD.

ZimmermanN, S. (1932): Über die Verbreitung und die Formen des Genus Orcula Held in den Ostalpen. - Archiv für Naturgeschichte, N.F., 1: $1-56$.

Zöller, L., Oches, E. A. \& McCoy, W. D. (1994): Towards a revised chronostratigraphy of loess in Austria with respect to key sections in the Czech Republic and in Hungary. - Quaternary Geochronology (Quaternary Science Reviews) 13: 465-472. 